\title{
Peace treaties and trade between the Kingdom of Naples and Tripoli in the eighteenth century*
}

\author{
Franca Pirolo \\ Università di Catania
}

\begin{abstract}
The purpose of this paper is to analyse the trade agreements that the Kingdom of Naples stipulated with the Regency of Tripoli during the eighteenth century, focusing on the specific contents of trade relations between the Kingdom and the Barbary State in the Mediterranean, at different historical times in Mezzogiorno (Southern Italy). The first treaty was signed in 1729, during Austrian rule in Naples; the second dates to 174I, during the Regency of Charles of Bourbon. The last trade treaty of the eighteenth century was stipulated in I785, under the government of Ferdinand IV. The study of those agreements has allowed some further insights into the relations between the Kingdom of Naples and the Regency of Tripoli in the Mediterranean of the eighteenth century, an important crossroads of trade, diplomatic relations and disputes between states.
\end{abstract}

Keywords: peace treaties, piracy, Kingdom of Naples, Regency of Tripoli, trade treaty.

* A first version of this paper was presented at the 19th Annual International Congress of the Mediterranean. Studies Association, University of Palermo (Italy), May 25th-28th, 2016. 
Tractats de pau i de comerç entre el Regne de Nàpols $i$ Trípoli al segle XVIII

\section{Resum}

L'article analitza els tractats comercials entre el Regne de Nàpols i la Regència de Trípoli al llarg del segle xvirI. S’evidencien els continguts específics de les relacions econòmiques entre el Regne i la potència barbaresca en el mar Mediterrani en diferents moments de la història del sud d'Itàlia. El primer tractat va ser signat l'any I729 durant el virregnat austríac, mentre que el segon és de I74I, sota el govern de Carles de Borbó. L'últim tractat va ser estipulat el I785, durant el regnat de Ferran IV. Mitjançant la lectura d'aquests documents, l'article mostra la vivacitat dels intercanvis comercials i de les relacions diplomàtiques al Mediterrani del segle XviII.

Paraules claus: tractats de pau, pirateria, Regne de Nàpols, Regència de Trípoli, tractat comercial.

Tratados de paz y comercio entre el Reino de Nápoles y Trípoli en el siglo XVIII

\section{Resumen}

Este artículo analiza los tratados comerciales entre el Reino de Nápoles y la Regencia de Trípoli en el siglo XviII. Se subrayan los aspectos específicos de las relaciones económicas entre el Reino de Nápoles y la potencia berberisca en el Mediterráneo en momentos diferentes de la historia del sur de Italia. El primer tratado fue firmado durante el virreinato austriaco, en I729, el segundo es de I74I y tuvo lugar durante el reinado de Carlos de Borbón, y el último fue estipulado en 1785 por Fernando IV. Con la lectura de estas fuentes, el artículo muestra la vivacidad de los intercambios comerciales y de las relaciones diplomáticas en el Mediterráneo del siglo XviII.

Palabras llaves: tratados de paz, piratería, Reino de Nápoles, Regencia de Trípoli, tratado comercial.

\section{Introduction}

The non-development of relations between Naples and the Ottoman Empire between 1500 and 1600 stemmed from the endemic state of

Pedralbes, 37 (20I7), II5-I32, ISSN: O2II-9587, DOI: IO.344/PEDRALBES2OI7.37.6 
war between the two countries. From the early I500s, after the conquest of the Neapolitan viceroyalty by Ferdinand the Catholic (I503), there had been continuous assaults of the Turkish fleet on the southern coasts, in constant conflict with Spain for possession of the territory. To these were added the corsairs from the Barbary States, primarily those of Algiers ${ }^{\mathrm{I}}$ and Tunis, formed in northern Africa under the protection of the Ottoman Empire. ${ }^{2}$ The Turks could set up an imposing fleet not only in the shipyards of Constantinople but also in those of the countries subject to their dominion, primarily Greece; and to these were to be added the fleets set up by the Barbarian corsairs. All began with the feats of the Barbarossa brothers, Oruç and Hair el-Din, Greek sailors of the island of Lesbos, who, at the beginning of the sixteenth century, reached the coasts of North Africa to give themselves to the corsa (piracy), just in the period when the Sultan Bayezid II launched a great offensive in the east, incorporating Syria and Egypt into the Ottoman Empire. ${ }^{3}$ Spain, instead, had a different naval organization and a less numerous fleet: ${ }^{4}$ also there were to be added the fleets of the subject Neapolitan ${ }^{5}$ and Sicilian kingdoms. ${ }^{6}$ Valuable help came from

I. John B. Wolf, The Barbary Coast: Algeria under the Turks, Norton, New York, 1979.

2. Salvatore Bono, Corsari nel Mediterraneo. Cristiani e musulmani fra guerra, schiavitù, commercio, Mondadori, Milano, 1997 and Un altro Mediterraneo. Una storia comune fra scontri e integrazione, Salerno, ed., Rome, 2008.

3. Mirella Mafrici, Carlo Ve i Turchi nel Mediterraneo. L'ultima spedizione di Khair-el-din Barbarossa (I544-44), in F. Cantù, M. A. Visceglia, eds., L'Italia di Carlo V. Guerra, religione e politica nel primo Cinquecento, Viella, Rome, 2003, pp. 639-657.

4. Irving I. A. Thompson, Guerra y decadencia. Govierno y administraciòn en la Espana de los Austrias, I560-I620, Ist ed. London, 1976.

5. Maria Sirago, "La flotta napoletana nel viceregno spagnolo (I507-I598)», Frontiera d'Europa, n. I (1999), pp. III-I72.

6. Valentina Favarò, «La escuadra de galeras del regno di Sicilia. Costruzione, armamento, amministrazione (xvi secolo)", in R. Cancila, ed., Mediterraneo in armi (secc. XV-XVIII), Associazione Mediterranea, Palermo, 2007, pp. 397-428 (Mediterranea, Ricerche Storiche. Quaderni, 4). 
the Knights of Malta, ${ }^{7}$ who exercised the $\operatorname{cors}{ }^{8}{ }^{8}$ and from those of the "particolari», formed at the time of Charles V (Genovese, Toscana, Papal, Savoyard). 9 Among these main protagonists of the Mediterranean scenario there was also Venice, with its mighty fleet, often in aid of Spain during particular moments of crisis such as the Battle of Lepanto (I57I), which, however, saw the decrease of its power during the I6oos because of the Ottoman Empire, in its continuous attempt to establish control of the Mediterranean. ${ }^{10}$ Added to all this was the problem of «flag camouflage», analyzed by Maria Stella Rollandi for the Genoese Navy; that is, raising a different banner to hide the true nationality of the ship and carry out the corsa. ${ }^{\text {II }}$ This situation remained unchanged throughout the period of the Spanish domination in Southern Italy (1503-1707), to the point that to be able to trade, merchant ships had to be protected by war ships. In addition, the same sailors, often captured and sold as slaves, in the Neapolitan capital and the Gulf had created religious «guilds» called «Monti dei Padroni di Barche e Marinai» (Funds of Ship Captains and Sailors), a kind of insurance, which were to provide for the various needs of themselves and their families, disabilities, deaths, dowry to the daughters and, above all, ransom from slavery. ${ }^{12}$ During the Austrian rule (1707-I734) the problem remained unchanged

7. Ettore Rossi, Storia della marina dell'Ordine di San Giovanni di Gerusalemme di Rodi e di Malta, Società Editrice d'arte illustrata, Rome-Milan, 1926.

8. Peter Earle, Corsairs of Malta and Barbery, Sidgwich and Jackson, London, I970.

9. Bruno Anatra, Le armi e il mare, in G. Galasso, A. Musi, eds., Carlo V, Napoli e il Mediterraneo, Atti del convegno internazionale, published in Archivio storico per le province napoletare, 4I (200I), pp. I24-I25.

Io. Giovanni Muto, Percezione del territorio e strategia del controllo nel Mediterraneo spagnolo (secoli XVI- XVII), in R. Villari, ed., Controllo degli stretti e insediamenti militari nel Mediterraneo, Laterza, Bari, 2002, pp. I69-190.

II. Maria Stella Rollandi, «Mimetismo di bandiera nel Mediterraneo nel secondo Settecento. Il caso del Giorgio inglese», Società e storia, I30 (2010), pp. 72I-742.

I2. Giuseppe Di Taranto, I Monti dei padroni di imbarcazioni e dei marinai, in A. Guenzi, P. Massa, A. Moioli, eds., Corporazioni e gruppi professionali nell'Italia

Pedralbes, 37 (20I7), II5-I32, ISSN: O2II-9587, DOI: IO.344/PEDRALBES2OI7.37.6 
to the point that precise orders were given for the construction of vessels to be placed to defend the merchant ships carrying the foodstuffs for the annonae supply of Abruzzi and Puglie Capital. ${ }^{13}$ For this reason the emperor Charles VI had decided to begin negotiations with the Sublime Porte and the Barbary States, to limit the corsa and create more favorable conditions for trade. On July 2Ist, I7I8, to end the Second War of Morea, ${ }^{\mathrm{I}}{ }^{4}$ the Austrian Emperor, Charles VI, signed a peace treaty with the Ottoman Empire in Passarowitz. It granted free trade between the countries of the two contracting kings, and freedom of navigation for their ships in the Black Sea, «sicchè caricate le mercanzie si potessero trasportare in Costantinopoli, nella Crimea, in Trebisonda, in Sinope e in altri empori di quel mare senza impedimento di sorta alcuna» (so that the loaded merchandise could be transported in Constantinople, Crimea, Trabzon, Sinope, and other trading points on that sea without impediment whatsoever), stating in chapter XIII a clause of vital importance, namely that «merchants of both nations could trade freely». ${ }^{15}$ The agreement stipulated that the maximum rate of duties on export and import should be fixed at $3 \% .^{16}$

moderna, Atti del Convegno, Rome 26-27 September I997, F. Angeli, Milan, I998, pp. 589- 6I2.

I3. Sirago, «La ricostruzione della flotta napoletana e il suo apporto alla difesa dei mari nel viceregno austriaco (I707-I734)", Archivio Storico per le Province Napoletane (20I6), pp. 7I-98.

I4. Kenneth M. Setton, Venice, Austria, and the Turks in the Seventeenth Century, The American Philosophical Society, Philadelphia, I99I, pp. 426 ss.

I5. Sirago, "La ricostruzione della flotta napoletana»; Istrumento di pace Stabilita e Firmata in Passarowitz nel Regno di Servia a di 22 del Mese di Luglio I7I8 tra Carlo VI e il Sultano Achmedhan, Sebastiano Porsile Stampatore della Reg. Generale, Naples, I7I8.

I6. Giuseppe F. De Tiberiss, «Le Riflessioni sopra il commercio di Federico Valignani. Alle origini del pensiero riformatore nel regno di Napoli», Frontiera d'Europa, VII, n. I-2 (200I), I, p. I82 and II, p. 230. 


\section{Austrian era (I707-I734)}

A few days after the signing of peace, the emperor Charles VI wanted to define even better the relations with the Sublime Porte, stipulating on July 27th, I7I8 a very significant Treaty of Trade, recalls Antonio di Vittorio, «not only in the new course of relations between the Empire — and, therefore, also the Kingdom of Naples — and Sublime Porte but for the start of an expansion of the Habsburg commercial area», although it «stipulated in an imperial perspective, was the cause of friction and trade conflicts between the Kingdom of Naples - one of the most peripheral provinces of the Empire - and the Sublime Porte itself». ${ }^{17}$ In fact, at the end of the long conflict over the Spanish succession the emperor had succeeded in further expanding his maritime possessions by obtaining possession of Sicily in 1720 with the Treaty of The Hague. ${ }^{18}$ It was therefore necessary to reorganize the entire port system of the island, starting with the Messina port, which had always been an important place of exchange in the Mediterranean. ${ }^{19}$ At the same time, in line with the mercantile policy pursued by the Habsburg government, the Adriatic port system was also to be reorganized: ${ }^{20}$ so on I8th March, 1719, the status of Duty Free Port was granted to Trieste and Fiume, a

17. Antonio Di Vittorio, Il Coinvolgimento del Regno di Napoli, provincia austriaca (1707-I734), nel trattato commerciale del I7I8 tra Impero asburgico e Porta ottoma$n a$, in A. Giuffrida, F. D’Avenia, D. Palermo, eds., Studi storici dedicati a Orazio Cancila, Associazione Mediterranea, Palermo, 20II, III, p. 928.

I8. Francesca F. Gallo, «La Sicilia di Carlo VI: riforma amministrativa e ricerca del consenso (1719-1734)", Cheiron, 2I (1994), pp. I87-226.

19. Salvatore BotTari, The port of Messina (I59I-I783), in M. D'Angelo, G. Harlaftis, C. Vassallo, eds., Making waves in Mediterranean. Sulle onde del Mediterraneo, Proceedings of the 2nd MMHN Conference Messina and Taormina, 4th-7th May 2006, Istituto di Studi Storici "Gaetano Salvemini», Messina, 2010, pp. 626- 650: 643.

20. Daniele Andreozzi, «La gloria di un dilatato commercio. L'intrico delle politiche e lo sviluppo di Trieste nell'Adriatico centro settentrionale (I700 - I730)», 
decree also confirmed for Messina in $1728 .^{21} \mathrm{~A}$ few months later, on 27th May, 1719, the "Compagnia Caesarea Orientale» was established, on the model of the British and Dutch, based in Vienna and Trieste, which was to become an instrument for the commercial development of the Empire. ${ }^{22}$ Within this context the southern viceroyalty benefitted from the new course of the Habsburg politics, so that here also there were diplomatic negotiations, in the wake of those stipulated with the Sublime Porte. Thus, economic relations between the Ottomans and the Neapolitans were regulated by trade treaties, considered as the main instruments to encourage trade exchange. ${ }^{23}$ The Kingdom of Naples could expand its commerce in the Levant only through treaties of amity and trade, «non-aggression pacts», with the Barbary States; therefore, it was thanks to this cooperation that trade relations between European states and the Ottoman Empire intensified. The need for more lucrative trade routes in the Mediterranean, and the necessity of preventing the increasingly frequent attacks by the Barbary pirates, led the Kingdom of Naples to compel Barbary rulers to sign non-aggression pacts. A lasting peace through the nations would have protected them from the menacing presence of the pirates and granted them free trade and navigation, as well as the safety of their ships and the securi-

Mélanges de l'École française de Rome-Italie et Méditerranée moderne set contemporaines, I27-I (2015), pp. I-I8 [on-line journal available at https://mefrim.revues.org/20I5].

2I. Maria Sirago, «Il 'sistema' portuale italiano in età moderna», in A. Guimerà, D. Romero, eds., Puertos y sistemas portuarios (siglos XVI -XX), Actas del Coloquio Internacional El Sistema Portuario Español, Ministerio de Fomento, Madrid, 1996, pp. $53-76$ e $64-65$.

22. Di Vittorio, Gli austriaci e il Regno di Napoli: 1707-I734: ideologia e politica di sviluppo, 2 vol., Giannini, Naples, 1973, p. 36.

23. De Tiberis, «Le Riflessioni sopra il commercio di Federico Valignani», p. I82; Sirago, Le città e il mare. Economia, politica portuale, identità culturale dei centri costieri del Mezzogiorno moderno, ESI, Napoli, 2004, p. 32; M. Mafrici, C. Vassallo, eds., Sguardi mediterranei tra Italia e Levante (XVII-XIX secolo), Malta University Press, Malta, 20I2; L. Mascilli Migliorini, M. Mafrici, eds., Mediterraneo e Mar Nero. Due mari tra età moderna e contemporanea, ESI, Naples, 2012. 
ty of their crews when entering ports in both countries, thus respecting the principle of reciprocity.

During the conquest for the Mediterranean, ${ }^{24}$ declarations of war alternated with peace treaties, while sea routes were threatened by corsairs and pirates, ${ }^{25}$ whose power had gradually increased, concentrating their raids on coastal populations and merchant vessels from the southern kingdom. Pacts often lasted only a short time, because of frequent violations of the treaty clauses even before the ratification of the treaty itself. ${ }^{26}$ Actually, the temporary nature of peace treaties signed by Muslim regents can be explained by their need to raid and, consequently, to alternate periods of peace with periods of war against the other states in order to make money from stolen goods and ransoms paid for captured slaves, ${ }^{27}$ the most profitable merce (goods) for both Christians and Muslims. ${ }^{28}$

Since then, the Treaty of Commerce with the Ottoman Empire (of July 27th, I7I8) probably had been a model for trade negotiations with the Barbary States. ${ }^{29}$

Treaties were often infringed by Barbary rulers because fare bottino (plundering) Neapolitan merchant vessels had become a modus viven$d i$, above all starting from the first decade of the century, with the Si-

24. Fernand Braudel, Civiltà e imperi nel Mediterraneo nell'età di Filippo II, Einaudi, Torino, 1986.

25. Salvatore Bono, «Malta e Venezia fra corsari e schiavi (secc. XvI-XviII)», Mediterranea Ricerche storiche, III, n. 7 (2006), pp. 213-222.

26. Antonio Di VitTorio, Il commercio tra Levante Ottomano e Napoli nel secolo XVIII, Giannini, Naples, 1979.

27. Salvatore Bono, «Storiografia e fonti occidentali sulla Libia (I5IO-I9II)», Quaderni dell'Istituto Italiano di Cultura di Tripoli nel Settecento, n. s., Rome, 1982.

28. Salvatore Bono, Schiavi. Una storia mediterranea (XVI-XIX secolo), Il Mulino, Bologna, 2016.

29. Michelangelo Schipa, Il Regno di Napoli al tempo di Carlo Borbone, Società editrice Dante Alighieri, Roma, I923; F. Canale Cama, D. Casanova, R. M. Delli Quadri, L. Mascilli Migliorini, eds., Storia del Mediterraneo moderno e contemporaneo, Guida, Naples, 2009, p. 193.

Pedralbes, 37 (20I7), II5-I32, ISSN: O2II-9587, DOI: IO.344/PEDRALBES2OI7.37.6 
gnorìa dei Quaramânlî (Karamanli dynasty) governing Tripoli, when Barbary pirates gained control of the economic power, taking advantage of the weak Neapolitan fleet. ${ }^{30}$

Nevertheless, treaties were not always economically profitable. In this regard, Bianchini wrote:

L'unico trattato che apportò qualche vantaggio fu quello del 1725 (...), inoltre due convenzioni del 1726 fatte con gli Stati d'Algeri e Tripoli che fermarono di potere i nostri concittadini colà liberamente trafficare; ma poiché inutile era venire a nudi patti con quei pirati, così niun bene a noi ne derivò, e al contrario le marine del nostro reame seguitarono ad essere esposte alle loro incursioni. ${ }^{3 \mathrm{I}}$

The study of the pragmatics (laws) of the kingdom helped us to deduce the specific content of the treaties of perpetual peace, amity, trade and navigation signed in the eighteenth century between the Kingdom of Naples and the Barbary States, as well as the economic situation of the geographical areas involved. First measures were taken by the Austrians in 1729 in order to guarantee to Neapolitan ships free

30. Francesco Conò, «Una relazione veneta su Tripoli nel Settecento», Rivista delle colonie italiane, IV (I930), pp. I092-IIO2; Conò, "Una relazione veneziana dell'anno 1784 sulle Reggenze di Tunisi, Algeri e Tripoli», Tripolitania, I, n. II (1931), pp. 9-I7; Corò, «Il Regno di Tripoli in una descrizione del I768», Tripolitania, III, n. 9-I3 (I933); Ferdinando Buonocore, "Consoli o procuratori di Tripoli e di Tunisi nelle Due Sicilie (e cenni ad altri consoli o agenti dei paesi musulmani nell'epoca precoloniale», Africa, XXXI, n. 2 (1976), pp. 257-276; Teobaldo FILESI, Un secolo di rapporti tra Napoli e Tripoli, I734-I835, Giannini, Naples, 1983; Francesco BarbaGaLLO, "Discussioni e progetti sul commercio tra Napoli e Costantinopoli nel '700", Rivista storica italiana, 2 (1971), pp. 264-296.

3I. "The only advantageous treaty was signed in 1725 [...], in addition to two conventions stipulated in 1726 with the States of Algiers and Tripoli confirming free trade and navigation for our citizens; however, coming to terms with the pirates was completely useless to us, because our Royal navies could not escape further pirate attacks.» Ludovico Bianchini, Storia delle finanze del Regno delle Due Sicilie, Luigi De Rosa, ed., Naples, ESI, 197I, p. 340. 
navigation of the Mediterranean. ${ }^{32}$ The contracting parties, following the example of a previous treaty signed in 1726 with the Regency of Tunis and through the mediation of the Ottoman Porte, ${ }^{33}$ concluded an agreement consisting of thirteen articles about reciprocal freedom of navigation both for vessels and crews.

The first article stated:

Per l'avvenire tra le navi e i sudditi dei rispettivi Stati tanto per terra come per mare sieno tolte e proibite tutte le inimicizie e offese; di modo che dal giorno di questa sottoscrizione sia data piena soddisfazione, ed intera restituzione dé danni che fossero stati fatti dall'una e l'altra parte onde le navi e i sudditi che da questo tempo in poi fossero presi e fatti schiavi sieno restituiti e poste in libertà con tutte le cose e tutto ciò che appartiene a quelle $[\ldots] .{ }^{34}$

Moreover, Tripolitan corsair ships were prohibited from hindering the navigation of allied ships with flags and passports issued by the competent authority; it was also established that both parties should help each other in case of need, and that Tripolitan ships were allowed to visit merchant vessels to control patents and passports only with the prior consent of the captain of the ship. ${ }^{35}$

The king had the right to appoint an imperial consul, or plenipotentiary, and send him to the main Levantine ports of call to issue passports and patents to his subjects. Consuls acted as judges for set-

32. Nuova Collezione delle Prammatiche del Regno di Napoli, V. Foedus Caesarerum et Tripolitum, Napoli, Stamperia Simoniana, I804, pp. I54-I62.

33. Mirella Mafrici, «Diplomazia e commerci tra il Regno di Napoli e la Sublime Porta: Guglielmo Maurizio Ludolf (1747-1789)", in M. Mafrici, ed., Rapporti diplomatici e scambi commerciali nel Mediterraneo Moderno, Rubbettino, Soveria Mannelli, 2005, pp. I5I-I72.

34. "Hostilities between the navies and the populations of the contracting States shall be forbidden by land and sea, so that, from now on, the damage done to date can be repaired, the slaves set free and the stolen goods given back to their owners)", in Nuova Collezione delle Prammatiche del Regno di Napoli, V, pp. I54-I62.

35. Ibidem. 
tling disputes between subjects, and they were free to return to their native country within three months of the breakdown of the treaty of amity. Bilateral negotiations brought about the end of hostilities, compulsory mutual aid, and prohibition on holding crewmen in slavery.

\section{Under the first Bourbon kings (I734-I806)}

From 1734, when it gained its independence under the rule of Charles of Bourbon, the Kingdom of Naples became involved in a wider network of trade flows, following the mercantile plans proposed by the king's minister. ${ }^{36}$ In I740, the Ottoman Porte and the Kingdom of Naples signed a twenty-year agreement. Thanks to the improvement of the Neapolitan merchant navy, diplomatic and trade relations between the two states started in a peaceful atmosphere, thus creating favorable conditions for trade exchange. ${ }^{37}$ The agreement was also the basis for further negotiations, which led to a treaty signed by the Kingdom of Naples and Tripoli in I74I..$^{38}$ Tripoli, as a centre of commercial activities, was not as important as Constantinople, which was considered one of the chief trading places of the Empire, both for its population density, and for being a junction of the trade surplus of the other provinces. ${ }^{39}$ However, expecting some benefits from trade, the Kingdom of Naples stipulated another treaty with the Regency of Tripoli through Giacinto Voschi, minister plenipotentiary of King Charles, acting as an intermediary. In fact, unofficial negotiations had begun a few years before the treaty was signed. A Jewish trader, Giuseppe Zevi, had been sent to Tripoli in order to promote friendly relations between the two coun-

36. Maria Sirago, Le città e il mare, pp. 33 ss.

37. Massimiliano PezzI, Aspettando la pace. Il Levante ottomano nei documenti diplomatici napoletani (I806-I8I2), Studio Zeta, Rossano Scalo, 1992.

38. Archivio di Stato di Napoli (ASN), Affari Esteri, Costantinopoli, n. I87, in Di VitTorio, Il commercio tra Levante Ottomano e Napoli nel secolo XVIII, p. 48.

39. Ibidem, p. II4. 
tries: it was his task to ingratiate himself with the Bey of Tripoli in an informal manner, by granting him privileges and giving him wheat as a gift. Indeed, Zevi, with the help of another Jewish trader acting as a mediator, Salomone Kalfon, a confidant of the Bey, was just testing the waters for the treaty that the Bey and Giacinto Voschi were going to sign. ${ }^{40}$ Zevi reported that Tripoli was not really a strong trading power because of the limited resources of its population, and that the Bey was more interested in private trade relations with his subjects than in slave redemption. Zevi also gave an accurate account of the trade in goods between the Regency of Tripoli in Barbary and the Kingdom of Naples, mainly consisting of food and local manufactured goods such as "vini, formaggi ordinari, sardine salate, panni ossia drapperia di lana, panni di seta, cioè damaschi, velluti, taffettà (... che) paga in Tripoli di dogana cinque per cento, e due per cento di consolato». ${ }^{4 \mathrm{I}}$

Finally, some of the goods usually sent to Tripoli «si manda[va]no in Tripoli», like "panni ordinari del Regno di I4 o Is carlini la canna, rossi, turchini, verdi, gialli e altri colori, vino, castagne, mele, ed altri frutti, carta grossa, zagarelle di seta e altre minute seterie, zulfaro ed alcuni altri generi, ma in poca quantità, atteso che il paese è piccolo».42 All goods were stored in the Neapolitan harbour, in a building called «Immacolatella Vecchia», or «Deputazione della Salute» (Deputation of Health),

40. ASN, Affari Esteri, f. 44IO, in FILESI, «Un interessante capitolo delle relazioni tra Napoli e Tripoli: I739-I747", p. 232.

4I. "Wine, cheese, salted sardines, woolen drapery, silk cloths like damask, velvet and taffetta, for which a five percent duty had to be paid in Tripoli, in addition to two percent due to the Consulate.» ASN, Affari Esteri, f. 44IO, in FILESI, «Un interessante capitolo delle relazioni tra Napoli e Tripoli: I739-I747", p. 232.

42. "Plain coloured fabrics made in the Kingdom and sold at I4 or I5 carlinos per perch - mainly red, turquoise, green, yellow - wine, chestnuts, apples, and other fruits, cartridge paper, silk ribbons and some other small articles made of silk, sulphur and other goods, were sent in small quantities because it was a small country.» ASN, Affari Esteri, f. 44Io. 
built by Antonio Vaccaro by order of Charles of Bourbon (about I740), ${ }^{43}$ whereas ships were usually detained in "quarantine» at the island of Nisida, near Naples. ${ }^{44}$ The word comes from the seventeenth-century Venetian dialectal Italian quarantena, so called because the length of the quarantine was typically forty days: during the epidemic of bubonic plague, the Black Death, it referred to the period of isolation or detention imposed upon ships when suspected of carrying a contagious disease, before passengers and crew were allowed to board. ${ }^{45}$ Quarantine can be applied to humans, but also to animals of various kinds, and both as part of border control, also within a country. ${ }^{46}$

As for the goods coming from Tripoli, Zevi mentioned, «si cava[no] di Tripoli lane, rame, penne per cappelli o altro, grani, oglio, cuoi per scarpe, cera, dattali, zafferano, barracani di lana per marinai» (wool, copper, feathers for hats or anything else, grains, oil, leather for shoes, wax, dates, saffron and woolen barracans for seamen). ${ }^{47}$

The agreement signed in Tripoli on June 3rd, I74I, by Charles of Bourbon and Hakmet Quaramânlî, the Bey Bassà, confirming the inviolable principle of peaceful relations between the two countries, con-

43. Maria Raffaela Pessolano, Il porto di Napoli nei secc. XVI-XVIII, in G. Simoncini, ed., Sopra i porti di mare, II, Il Regno di Napoli, Olschki, Florence, 1993, pp. 67-II5.

44. Giuseppe De Rinaldi, Napoli, Lazzaretto di Nisida, in N. E. Vanzan Marchini, ed., Rotte mediterranee e baluardi di sanità, Venezia e i lazzaretti mediterranei, Skira ed., Geneva- Milan, 2004, pp. 268-27I.

45. Raffaella Salvemini, A tutela della salute e del commercio nel Mediterraneo: la sanità marittima nel Mezzogiorno pre-unitario, in R. Salvemini, ed., Istituzioni e trasporti marittimi nel Mediterraneo tra età antica e crescita moderna, Consiglio Nazionale delle Ricerche, Istituto di Studi sulle Società del Mediterraneo, Naples, 2009, pp. 259-296.

46. Klaus Bergoltd, La fobia del contagio e le teorie mediche sul contagio, in Vanzan Marchini, Rotte mediterranee, pp. I49-I57.

47. ASN, Affari Esteri, f. 44IO, in FILESI, «Un interessante capitolo delle relazioni tra Napoli e Tripoli: 1739-I747", p. 232. 
sisted of seventeen articles..$^{48}$ Article III of the treaty dealt with prohibited goods like ammunition and weapons, «senza l'espresso consenso delle due Potenze contrattanti non potrà farsi commercio» (whose trade was not allowed without the consent of the two contracting powers); it was also prohibited to trade in those goods, whether abundant or scarce, that "convenisse ad una delle Parti contrattanti di sospendere l'estrazione o l'immissione, dalla quale sospensione l'altra non potrà offendersi qualora sarà generale, e comune a tutte le altre Potenze amiche» (one of the contracting parts judged most convenient to stop mining or placing on the market, and for which the other contracting part would not be offended if the measure taken involved other allied powers). It was also established that both the contracting countries had equal rights in the payment of duties, anchorage dues and stabling, fixed at $3 \%$. Some other clauses provided for the procedure concerning the appointment and duties of consuls and vice consuls, as well as rules relating to shipwrecks and slave redemption: they also made certain guarantees to warships and merchant vessels, such as mutual freedom of navigation and anchorage at each other's ports, in addition to the payment of the imposed duties on goods. It was a detailed set of regulations for the merchant navy, as $\mathrm{Di}$ Vittorio wrote. ${ }^{49}$ Indeed, article VIII also included the rules that warships belonging to the two powers had to obey when they met at sea (incrocio), or when their flags should be displayed. If warships met merchant vessels, two seamen from the first ship were allowed to board the vessel to check the validity of the patents:

E riconosciuto che sarà conforme all'esemplare (...) lo lascerà continuare il suo viaggio senza impedimento alcuno aiutandolo anche, se ne sarà richiesto. Essendo però trovata la patente dissimile od invalida, ciò non sarà una ragione per depredarlo, né tampoco per molestarlo ma solamente sarà la pena, a cui dovrà soccombere, regolata dalli rispettivi Gov-

48. Nuova Collezione delle Prammatiche, V. Foedus Regium et Tripolitum, pp. 338346.

49. Di Vittorio, Il commercio tra Levante Ottomano e Napoli, pp. 49ss. 
erni né di cui Stati sarà condotto, d'accordo però con il Console ed Agente dell'altra Potenza, che vi risiederà..$^{50}$

Merchant vessels sailed from Sicilian ports to Tripoli carrying «frumento, olio, sete, legumi, manne, formaggi, cascavalli, pistacchi, sommacco, amandole, Sali, tonnine, vino, salnitro, pannine, acquavite, cenere di soda, sovari, tartaro, uva passata, nocciole, coralli» (wheat, oil, silk, legumes, manna, cheese, caciocavallo, pistachios, sumac, almonds, salt, bonito, wine, saltpetre, wollen fabrics, aqua vitae, soda ash, cork, tartar, raisins, chestnuts, corals), whereas imported goods from Tripoli were «frumento, olio, cera, cottone, coirami, legumi, riso, manteca, formaggi, lana, lino, caffe, pelli di camello, tabacchi, cuscusu e barracani» (wheat, oil, wax, cotton, leather, legumes, rice, butter, cheese, wool, linen, coffee, camel leather, tobaccos, couscous and barracans) $)^{5}$. The main port of the island, indeed, its most important maritime trading place, was Messina; ;2 $^{2}$ but also important were, Palermo, Siracusa and Trapani, which represented, along with the Port of Messina, the four Deputazioni di Sanità

50. «And once it is verified that they are conforming to the original (...), the vessel can continue traveling unhindered or be helped if required. If a patent is not valid or not in compliance with the laws, the vessel will not be plundered or attacked, but it will have to pay a penalty established by the governmental authorities of the State where it will be conducted, in accordance with the residing consul and the consular agent of the country the vessel comes from», in Nuova Collezione delle Prammatiche del Regno di Napoli, V, pp. I54-I62.

5I. Vincenzo Epifanio, «Sulle relazioni politiche commerciali tra la Sicilia e la Tripolitania nella prima metà del secolo xvIII", Archivio Storico Siciliano, n.s., XxxvI (I9I2), pp. 439-440; FILESI, Un interessante capitolo delle relazioni tra Napoli e Tripoli, p. 23I, n. 37.

52. Michela D'Angelo, «The Emporium of Trade of the Two Seas. The Relaunching of the Port of Messina, I784-1815", in M. D'Angelo, G. Harlaftis, C. Vassallo, eds., Making waves in the Mediterranean. Sulle onde del Mediterraneo, pp. 65I667, and «Navigando tra due Stretti (I800-06). Navi, merci e mercanti tra Messina e i Dardanelli», in M. Mafrici, C. Vassallo, eds., Sguardi mediterranei tra Italia e Levante (XVII-XIX secolo), pp. 83-99. 
(quarantine stations) concerned with foreign trade..$^{53}$ In Sicily, wheat and oil were so abundant that the island made a great profit from trade. ${ }^{54}$ Besides, importing of these goods from Tripoli was abolished, thus pursuing a double purpose: to preserve the agriculture on the island, and to economize on duties. Furthermore, trade with the Kingdom of Naples increased thanks to food requests from the Regency in Tripoli, where provisions were carried mainly as gifts expressing friendship and respect for the agreement signed by the two countries. As part of the intricate European historical background during the war of the Austrian Succession, the I740s also witnessed remarkable events like Muslim fickleness, unjustified raids by Neapolitan corsairs, widespread unrest among Tripolitan subjects who could not conduct "corsa al Mediterraneo" (guerre de course in the Mediterranean) and, finally, the unexpected suicide of Hakmet Quaramânlî in I745. These circumstances culminated in a declaration of war by Tripoli against Naples, and the ultimate breakdown and severing of the diplomatic relations and trade flows between the two countries. 55

Under King Ferdinand, merchant shipbuilding increased very much in the shipyards of Piano and Meta (Sorrentine peninsula). Therefore, in consideration of the benefits from a previous trade agreement stipulated between Tripoli and Charles III, King Ferdinand decided to renew it on September Ioth, I784. ${ }^{56}$ He signed another agreement consisting of thirty-nine articles, which was ratified with Ahlì Quaramânlî on August 28th, I785. It stated that warships or corsair ships meeting a

53. G. Simoncini, ed., Sopra i porti di mare, III. Sicilia e Malta, Olschki, Florence, 1997.

54. Salvatore Bottari, «Trade and Politics between Naples, Sicily and The Ottoman Empire during the Kingdom of Charles of Bourbon (I734-1759)», in H. Ersin Avci, T. Tarjh Kurum, eds., Türk Denjzcilik Tari $h_{j} B_{j} l d_{j} r_{j} l e r$, Proceedings of the International Symposium of Piri Reis and Turkish Maritime History, Turk Tarik Kurum, Ankara, 20I4, pp. I49-155 and 269-27I.

55. FILESI, Un interessante capitolo delle relazioni tra Napoli e Tripoli, pp. 250-25I.

56. Nuova Collezione delle Prammatiche, V. Foedus Regium et Tripolitum, pp. 46I-478.

Pedralbes, 37 (20I7), II5-I32, ISSN: O2II-9587, DOI: IO.344/PEDRALBES2OI7.37.6 
Neapolitan merchant vessel at sea would not attack each other, in respect of the principle of freedom of navigation, provided that proper documentation — such as passports issued by the Bey Bassà and certification issued by the Spanish consul — could be inspected upon request. If not, they would have been considered pirate ships. They were not allowed to conduct raids against ships ten leagues off the coast of Spanish dominions either; as a matter of fact:

I passeggeri di qualsiasi nazione a bordo dei bastimenti spagnoli, così come i passeggeri spagnoli a bordo di qualsiasi bastimento nemico di Tripoli che si predasse, resteranno liberi con tutti i loro effetti, e mercanzie, anche nel caso che il bastimento nemico si fosse difeso. Lo stesso si farà con i passaggieri forestieri che li Spagnuoli trovassero né bastimenti Tripolini, e con i Tripolini a bordo di bastimenti nemici di Spagna. ${ }^{57}$

In turn, the Bey Bassà of Tripoli could refuse to give help to armed Barbary ships that came into port to wage war against the Spanish, so it was established that any [subject] taken prisoner in Tripoli «sarà libero in esse, come fosse in Ispagna» (will be considered a free man, as if he were in Spain). Wherever they came from, pirate ships entering Tripolitan ports were seized with all their merchandise and kept there for a year, whereas Spanish ships had to be delivered directly to the consul..$^{58}$ Warships, corsair ships and merchant vessels of both the contracting countries could enter all the ports of their dominions freely, and get everything they needed at a good price. Furthermore, the Bey Bassà made a commitment to keep the most powerful foreign ships in his ports for at least a couple of days to facilitate the departure of Spanish ships

57. «Foreign passengers travelling on Spanish vessels, as well as Spanish passengers on any Tripolitan enemy vessel being assaulted, shall be set free with all their belongings and merchandise, even if the enemy vessels resisted. The same applies to foreign passengers Spanish will find travelling on Tripolitan vessels, and to Tripolitans aboard any vessel enemy to the Spanish.» Nuova Collezione delle Prammatiche, V. Foedus Regium et Tripolitum, pp. 338-346.

58. Ibidem. 
from the port. The captain of a Spanish ship was required to contact the Consul before the Bey Bassà, as soon as he reached the port. Guard boats usually escorted the ships to the port, where they received from the Rais della marina (Captain) an iron chain to prevent the slaves from taking possession of the Lancia (launch). All ships had to pay 27 piasters for anchorage duty and for entrance and departure duty, whereas no anchorage duty was imposed on emergency mooring. Trade was permitted in all ports of the Regency of Tripoli, where a single duty rate of 3\% was imposed, and the same applied to Tripolitan subjects in Spanish dominions. No entrance duties were charged on prohibited goods such as "polveri, palle, cannoni, schioppi, zolfo, legni da costruzione, peci, catrame, ecc.» (gunpowder, balls, cannons, shotguns, sulphur, timber, pitch, tar, etc.), neither were taxes on breaming and hog (diritto di carena e "di dar sego») or departure duties on goods remaining unsold and loaded on board the ship again. The last articles of the treaty sanctioned the right of His Majesty the Catholic King to appoint Consuls in Tripoli, who had the power "di assistere e patrocinare pubblicamente i sudditi di Spagna» (to assist Spanish subjects and act as attorney for them publicly). 59

Following Antonio Genovesi's mercantilist view of economics and his scholar Ferdinando Galiani's contributions, in 1787 the Kingdom of Naples and Russia signed a profitable treaty establishing a new trade route in the Black Sea. However, this new trade, interrupted by wars at the end of the eighteenth century (like the second Russo-Turkish war, ending in 179I), increased only after the Restoration, when the port of Odessa experienced extraordinary development (I8I5). ${ }^{60}$

59. Ibidem.

6o. Maria Sirago, «Il consolato napoletano nel Mar Nero e lo sviluppo di Odessa tra la fine del '7oo e la prima metà dell'8oo', in Mafrici, Mascilli Migliorini, $M e-$ diterraneo e Mar Nero, pp. 203-233. 